\title{
Talking Past Each Other: On Common Misperceptions in the Rule of Law Debate
}

\author{
Attila Vincze
}

\section{INTRODUCTION}

Hungary is an enfant terrible of the European Union, an illiberal or hybrid regime (Krekó and Zsolt 2018), a quasi-Turkey or quasi-Russia in the EU, and many are perplexed how such a regime could be part of the EU sharing common values set out in Article 2 of the EU Treaty, which surely could not join the club today. ${ }^{1}$ Whereas many analyses have described the changes experienced during the last decade, some others

${ }^{1}$ Halmai (2018b, p. 16): "Model case of constitutional backsliding from a full-fledged liberal democratic system to an illiberal one with strong authoritarian elements". See further Kochenov (2017). For a more popular account see The Economist (2019).

\section{A. Vincze $(\otimes)$}

Andrássy University Budapest, Budapest, Hungary

e-mail: attila.vincze@andrassyuni.hu 
lack basic factual knowledge or misunderstand facts ${ }^{2}$ which again helps the Hungarian government to point out that condemnations are baseless allegations stemming from lacking knowledge or prejudice. Many more write from a moral high ground, which does not really help to understand the undergoing processes but instead exaggerates a value-loaded debate as clashes of cultures, ${ }^{3}$ and in doing so basically supports the denunciated regime, which gladly points out that the critique is nothing more than further evidence of the Spenglerian Downfall of the Occident.

On the other hand, it is also baffling that the EU tolerates this regime as long as it does, if the latter (as it is alleged) so obviously violates the fundamental values. While there were surely measures intended to save the EU's core values, like the new Rule of law framework, the Justice Scoreboard and public condemnations, they have not proven to be effective. ${ }^{4}$ Many have written about lacking post-accession compliance (Schimmelfennig and Trauner 2009), or the ineffective procedure of suspending the rights of a member state according to Article 7 TEU (see also Chapter 1).

The following chapter is intended to show some misconceptions and misperceptions in the debate around Hungary as well as shortcomings of the EU policies vis-à-vis the country. It describes the present government's critique that the EU applies double standards when it comes to the rule of law and explores how the Commission might have contributed to

${ }^{2}$ Avbelj (2015, p. 51): "Much can get lost in translation across different epistemic sites between the narrators and the audience. Simultaneously, a lot can be added to the reports, thanks to normative biases of different sorts, which are especially present in the politically deeply divisive issues of the alleged cases of systemic defiance". These factual misunderstandings happen also in the case of renown institutions, such as the Venice Commission (cf. Vincze 2012), or in the case of the Sargentini report (cf. Ésik 2018; Bakó 2018).

${ }^{3}$ Poptcheva (2015, p. 3): "Some commentators and political actors tend to see the outrage of particular member states or EU institutions over specific developments in a given member state as ideologically motivated, as the battle between left-wing and right-wing convictions, or as a battle between different cultures (Kulturkampf)".

${ }^{4}$ Juncker greeting Orbán as "Hello, dictator" at the Riga Summit of the EU in 2015 is one of these examples, which showed less condemnation and more made the impression of getting used to the situation. The suspension of the membership of Fidesz in the EPP because of the very populistic election campaign against Jean-Claude Juncker depicting him as a muppet of George Soros, and in doing so recalling anti-Semitic connotations, seems to be one of the very few examples of effective counter-measures. 
this impression by remaining inactive when previous governments disregarded constitutionality and basic values. Moreover, the chapter depicts the argument that the EU's diagnosis of illiberal backsliding is too narrow. When assessing the quality of democracy in the country, the Commission almost exclusively focuses on recent legal changes and thereby overlooks other deficits such as corrupt tendering policies or questionable taxing schemes. Due to this incomplete diagnosis, the instruments currently being used to combat backsliding tendencies seem ill-suited or halfhearted. The chapter concludes by highlighting and discussing possible improvements of EU strategies towards backsliding states.

\section{Misperception One: Birth of Illiberalism}

One of the prevailing narratives is that illiberalism, whatever the word might mean, was born after 2010 in Hungary, ${ }^{5}$ suggesting that the rightwing parties solely exploited a dissatisfaction with the former socialist government and the waves of the financial crisis of 2008, built up a mythos of failed democratic transition in 1989, and achieved a landslide victory enabling them to get rid of the old elite and to tailor-make the constitution. ${ }^{6}$ This narrative moreover suggests that the former constitution of Hungary was an embodiment of liberal values, had basically no crucial deficiencies, ${ }^{7}$ that the transition into a liberal democracy in 1989 was a successful one, and that the former socialist-liberal governments between 2002 and 2010 complied by and large with those very basic values of a liberal, democratic state governed by the rule of law. The widespread description of Hungary and Poland as "backsliding" the rule of law and liberal democracy also relies-albeit unspoken-on the proposition that the earlier constitution as a legal and a social (factual) construction complied with the European values. This reasoning is very tempting and easy to understand. However, the truth, as always, is a more nuanced one.

\footnotetext{
${ }^{5}$ Expressly so, e.g. Halmai (2018b, p. 15): “The weakening of liberal constitutional democracy in Hungary started after the landslide victory of the centre-right Fidesz party in the 2010 parliamentary elections".

${ }^{6}$ See the argumentation of Halmai with further references who summarises the liberal narrative, e.g. Halmai (2018b, p. 16) or Halmai (2014). Also see Magyar (2013).

${ }^{7}$ See Note 8 .
} 
Neither the constitutional transition (at least in Hungary) was as impeccable as some suggest, nor was the former government a flawless guardian of the rule of law. The former constitution was a transitory patchwork, which served satisfactory but was very far from perfect. At least three basic issues ${ }^{8}$ of the political transition remained unsolved which fuelled not only criticism but conspiracy-theories as well: (1) the transition left the former leaders of the Communist regime basically untouched, and they were not made responsible for the injustices that occurred; (2) the files and documents regarding the agents and collaborators of the former communist secret police were not made public, and the wider public still has no reliable information in this regard, which not only fuels rumours, but also legitimate worries of extortion; (3) restoration of property ownership confiscated during communism was at least very meagre (Hanley and Treiman 2004). However, this is not the place to deal with these topics, and especially to answer the question as to whether a property restoration was viable. These were symbolic issues stimulating not only well-reasoned criticism but also bogus theories of a deep state run by former communist networks. ${ }^{9}$ Maybe economic performance like the German Wirtschaftswunder (Westad 2017, p. 217f.) could have healed the wounds of the transition. Yet the economic mismanagement of Hungary since 2002, leading to an underperformance and to necessary austerity measures since 2006 without escaping an economic collapse at the end of 2008 , helped very much to blame the shortcomings of the political transition. According to some observers, and irrespective of the positive Freedom House scores (Kovács 2012), neither politically nor economically was the transition a success story. ${ }^{10}$ (On the other hand, the relative good economic performance of Hungary since 2010 and

${ }^{8}$ And there was a legion of further constitutional shortcomings and imperfections. One of the alleged problems with the new Hungarian constitutional system is the reorganisation of the organisation of the judiciary. Before 2012, there was a Judicial Office, an "institutionalised backroom" of the Supreme Court of Hungary, which was an independent body, and was thought to serve better judicial independence. Nonetheless, there is research showing that the reality did not live up to these expectations, cf. e.g. Fleck (2014) and Badó (2014).

${ }^{9}$ Very likely based on stories about an alleged network of former Nazi officials in Germany, which was very popularly dramatised, e.g. in The Odessa File by Frederick Forsyth.

${ }^{10}$ This was the conclusion of the recognised Hungarian political scientist, Péter Tölgyessy, see Bíró (2019) and Gergely (2017). Comparative economic data also suggest 
the growth of disposable income may also explain why a larger part of the Hungarian population considers the democratic decline as a cost of economic performance. $)^{11}$

The right-wing government of Orbán is often —and not without justification-blamed for arbitrariness and lacking respect for constitutional institutions. This instrumental use of the law, ${ }^{12}$ a rule by the law and not that of the law (Chronowski and Varju 2016), is often connoted with legislative measures adopted in order to appoint the right (politically suitable) "chap" for the right job (The Economist 2019), such as packing the Constitutional Court, ${ }^{13}$ the premature termination of the mandate of the President of the former Supreme Court of Hungary (Vincze 2015; Kosar and Šipulová 2018), or that of the Data Protection Ombudsman ${ }^{14}$ by amending the constitutional provisions (see also Chapter 10). Nonetheless, this kind of meddling with independent institutions was not alien to the former socialist governments of 2002-2010 either (Vincze 2018a). In 2000, a new financial supervisory authority was established during the first government of Viktor Orbán, and Károly Szász was appointed for six years as its president. In 2004, the newly elected socialist government wanted to dismiss him merely because he was appointed under the former government, and hence a new law was whipped through the parliament to this effect, which was also authorised by the Constitutional Court. ${ }^{15}$ And in the same year, the socialist government was trying to amend the law on the central bank in order to push over the governor of

that other CEE countries (Czech Republic, Poland, Slovakia or Slovenia) made much better use of the opportunities after the democratic transition.

${ }^{11}$ See instructively in this sense with a Central European comparison, Adamski (2019).

${ }^{12}$ For a broader theoretical understanding of law as an instrument of political aims, see Tamanaha (2006).

${ }^{13}$ Vincze (2014), the effects of the packing are clear to see nowadays. The Constitutional Court applies very different standards if a private individual lodges a complaint and if a government body submits one. A very shocking example was the recognition of fundamental rights of the National Bank of Hungary in order to quash an uncomfortable judgement for the Central Bank and the Government, cf. Kovács (2019), Chronowski and Vincze (2019).

${ }^{14}$ CJEU, Case C-288/12, Commission v Hungary (ECLI:EU:C:2014:237).

${ }^{15}$ Decision of the Constitutional Court $7 / 2004$ (III. 24.) $\mathrm{AB}$. 
the National Bank who was also appointed during the first Orbán government. ${ }^{16}$ These measures are essentially not very far from those of Orbán's government. The former socialist government simply lacked the necessary parliamentary majority to enact them on a constitutional level.

Moreover, the socialist PM Ferenc Gyurcsány secretly admitted to his fellow party members that he knowingly lied during the election campaign in 2006 and falsified data of the state budget in order to win these very elections. As this secret speech (The Guardian 2006; BBC 2006) came to light in the autumn of 2006, thousands demonstrated against the government in Budapest because of its flagrant disregard of democracy and the rule of law. Mainly due to the involvement of radical right groups and football hooligans, the demonstrations ended in violence, causing in turn fierce reactions of the police (Ilonszki and Kurtán 2007). During these events, the EU did not claim any violations of the basic values (such as democracy or the right to assemble), and therefore, the right-wing government of Orbán could easily allege that the problem was not the violation of the values but simply his person.

This narrative would be very similar to the problem of the European Monetary Union: it was built on self-reliance and hard budgetary constraints. However, they were quickly softened up as Germany and France broke the rules (Doukas 2005; Amtenbrink and de Haan 2006). And precisely because the two largest member states got away with rulebreaking, no one cared all that much until Greece basically went bankrupt due to the subprime lending crisis.

\section{Misperception Two: The VAlues of the European Union}

As is well-known, Article 2 TEU stipulates some inherent values of the $\mathrm{EU}$, the violation of which may lead to the suspension of the rights of the culpable member state. This procedure was introduced by the Treaty of Amsterdam but refined in the aftermath of the Haider affair (Lachmayer 2017; Schmahl 2000) and also in close proximity to the upcoming Eastern enlargement of the EU. It presupposes either a clear risk of a serious breach or an actual serious and persistent breach of the values of the Union, which begs the questions of what these values are, how far

${ }^{16}$ See nuanced Häde (2005). 
may the member states determine their meaning for themselves, and what is the relationship among these values.

The list encompassed in Article 2 TEU consists of a number of open-ended, value-loaded expressions which oscillate within a very broad repertoire of possible interpretations. From a law perspective, the terminology of the EU Treaty (freedom, democracy and equality, etc.) is rather an invocation than a definition, even if they surely make a claim to be of a prescriptive, and not simply of a descriptive, nature. The vocabulary does not only evoke different meanings in different languages (von Bogdandy and Ioannidis 2014), but it also depends on the political attitude and thinking (Fekete 2016), which makes wishful thinking (attributing the own individual concept to these values) very easy.

It is questionable, on the one hand, as to whether the political actors (basically the member states in their capacity as masters of the treaties) could have agreed on anything more specific (precisely because of the contested meaning of these words). However, on the other hand, they have not let the judiciary define them (in contrast to some other opentextured expressions), because the proceedings in which these values are of eminent importance are political ones (membership art. 49 TEU, suspension of membership art. 7 TEU and partnership art. 8 TEU).

Not only freedom, democracy and equality but also the rule of law have very contested connotations ${ }^{17}$ even if we can agree what their core might be. There is a common understanding that rule of law is an antithesis of arbitrariness. But there is an ongoing debate as to what arbitrariness means, how determinate and precise legal rules must be in order to avoid arbitrariness, what the limits of the discretion of any administration are, and how these requirements are to be reconciled with other compelling principles such as checks and balances and parliamentary government. ${ }^{18}$ Very lively is the discussion as to whether the rule of law is more than obeying the black letter of the law, and if so, what inherent values does it contain which should have also been protected

${ }^{17}$ See instructively Tamanaha (2004). Regarding its meaning in the EU-Treaty, see von Bogdandy and Ioannidis (2014, pp. 288-290).

${ }^{18}$ Significantly, the very same debate goes on in European administrative law without, however, the emotional slips, see Franchini (2004); for a very similar problem in the context of the ECHR, cf. e.g. Hwang (2013). 
against constitutional amendments. ${ }^{19}$ To put it otherwise, there is some plurality in the EU and different national legal orders embody different understandings of the substance of these values (Kombos 2010), and hence there is no value unity or uniformity in the Union despite the fact that member states share fundamental constitutional values (Avbelj 2015). It is necessary to pinpoint this circumstance as governments might easily find a definition of the rule of law which would comply with their own preference, and the alleged violations of the rule of law can be simply presented as cultural questions resulting from different (but basically equally acceptable) understandings of these values.

Similarly, one would understand democracy as a government of the people, but one might easily disagree as to whether democracy would require a certain form of direct or indirect involvement of the people, such as referenda (which in some member states does not exist) or a special kind of electoral system (proportional or majoritarian) (Morrison 2007). As there are many forms of democracy, there are many forms of the rule of law too (like formal and material, to mention the most obvious ones). There are also as many arguments in favour of a limited judicial or constitutional review as there are in favour of broader judicial powers (Griffith 1977; Tomkins 2005; Itzcovich 2015). Putting it more plainly, it is demanding to challenge the cut back of powers a constitutional court possesses as long as many member states have no such institutions at all. ${ }^{20}$ And it is precisely because of this particularity that EU actors should have put much more emphasis on what exactly is contrary to the

${ }^{19}$ Without going into details, the Rechtsstaatlichkeit (the German equivalent of the rule of law) is part of the Austrian and German constitutional thinking, having a more formalistic content in the first case and more substantial one in the second, cf. Jakab (2009). Likewise, Di Gregorio (2019) points out how the rule of law was differently understood in the different Central and Eastern European countries during the democratic transition. The different understandings of the common constitutional values appear vividly in the administrative law which effectuates the constitutional values at a very operational level, and the member states seem to have several permutations of the same values.

${ }^{20}$ Scheppele (2013) and Vincze (2014). This argument emerged in Hungary in 2019 during the Finnish presidency of the EU as, among others, the Prime Minister put forward that Finland should not criticise Hungary for the adopted model of the Constitutional Court because Finland has no such institution (Boffey 2019). This simplistic argument does not take into account the contextual differences between Central European and Scandinavian countries (see methodically, e.g., Kischel 2019). But precisely because of its simplicity, it is a very effective populist argument. Müller (2015), for instance, offers serious counter-arguments. 
common European core of the rule of law: the lacking independence, the diminished ambit of powers or the governmental bullying. ${ }^{21}$

As there are many theoretically possible variations of how to implement the rule of law, the question is to what extent member states are allowed to apply their own definition or operationalisation. ${ }^{22}$ Taking into account that the EU was built upon the principle of conferral (art. 5 TEU), the first question is as to whether the EU may object to any shortcomings of the law of a member state if that particular issue does not belong to its competences, as these remain with EU countries. As it follows from Art 4(2) TEU, fundamental political and constitutional structures belong to the identity of the member states which are to be respected. The very uneasy piece is to define the limits of the constitutional identity referred to in Art 4(2) TEU, as this is an essentially contested and disputed concept (Rosenfeld 2012; Jacobsohn 2006; van der Schyff 2016). Nonetheless, it has turned out to be an effective ideological tool to express defiance as pluralism and non-compliance as identity (Kelemen and Pech 2018; Mader 2019), especially because the phrase was not coined by the rebellious rogue states to protect their disobedience from overwhelming power of the EU law, but by the German Constitutional Court in order to protect the allegedly higher German constitutional standards from the European ones (Mayer 2015). A massive body of case law evolved describing and clarifying the meaning of the German constitutional identity, and the circumstances under which it may justify an eventual disobedience, which nonetheless also inspired the Hungarian Constitutional Court to borrow this expression. In doing so, it stylised the protection of illiberalism as basically doing the same

${ }^{21}$ This is not an easy undertaking if, for example, the European Court of Human Rights declares the remedies available at the Hungarian Constitutional Court to be an effective one, cf. Szalontay vs. Hungary, ECtHR Judgement of 12 March 2019 Application no. $71327 / 13$. A similar question arose in the case of Poland, as an Irish court questioned generally the independence of Polish courts and the effectiveness of judicial protection because of a reasoned proposal of the European Commission adopted pursuant to Article 7 (1) TEU, indicating that there is a real risk of a breach of the fundamental right to a fair trial in Poland, see Judgement of the CJEU (Grand Chamber) of 25 July 2018 case C-216/18 PPU, LM ECLI:EU:C:2018:586. As Lenaerts (2020) points out instructively, the CJEU crystallised many aspects of the rule of law, especially regarding the judiciary during the last decade.

${ }^{22}$ The European Court of Human Rights also accepts many different understandings of a "democratic society" and possible variations regarding the understanding of fundamental rights, see, e.g., Brems (1996). 
as the well-renowned and esteemed German institution (Vincze 2018b; Halmai 2018a).

The pluralism argument of the many national variations of common European values is often coupled with a resourceful and shrewd exploitation of comparative reasoning. The Hungarian government is usually very keen on pointing out that nearly every legal provision it enacted is borrowed from another country, implying that a critique of the Hungarian legislation is only fair if the country of origin of the contested provision is also blamed. Thus, "Frankenstein legislations" are born, which, like the wretched creature in Mary Shelley's book was a composite of body parts grafted together from cadavers, are cobbled together from different national laws of the member states into a monster which never originally existed (Scheppele 2013). The argumentation is, however, very simple: if the Hungarian rules are bad, then those other rules must be bad as well. The argumentation of the Hungarian government is at least superfluous and rather often manipulative, as evidence also suggests. ${ }^{23}$ But the real question is as to whether the nuanced and technocratic comparison can effectively counterbalance the simplistic communication.

There is a further strategy of softening up values, namely neighbourhood policy. The values of the EU according to Article 2 TEU are not only important for accession according to Article $49 \mathrm{TEU}$, but also for the neighbourhood policy (Bachmann 2019; Kellerhals and Baumgartner 2014). That is the reason why the Hungarian government is determined to point out how Ukraine violates the rights of the Hungarian ethnic minority (Gorondi 2018; McLaughlin 2018). Because the rights of the minorities are among the values enlisted in Article 2 TEU, a violation of them should require some steps of the EU in order to counter them. If the EU does not undertake these steps, Hungary can easily point out that the EU is not even-handed and the alleged violations of the rule of law are nothing else but a political witch-hunt.

A further (mainly neglected) dimension of values among those listed in Article 2 TEU is the conflict of hierarchy (Schorkopf 2016, p. 158). Art 2 TEU encompasses several equally weighted prima facie values beyond the rule of law, which, at least to some extent, have an uneasy relationship. Democracy and the rule of law, democracy and human rights (Jowell

${ }^{23}$ See regarding the media regulation Brouillette and van Beek (2012). 
2007; Saunders 2010), as well as freedom and equality, are concurring values, which nonetheless presuppose each other to some extent (complexio oppositorum). Democracy is basically a form of government by the people where decisions are made by the majority. The rule of law and human rights limit this freedom of the majority to decide whatever it finds proper, ${ }^{24}$ but on the other hand democracy presupposes equality (Pöschl 2014, paragr. 18), and we accept only the rule of a democratically enacted law (Müller 2015). Preferring the rule of law as a yardstick of the violations of EU values might be explained by the circumstance that the rule of law has a less contested meaning than the other values mentioned in Article 2 TEU (Schorkopf 2016, p. 158). But the prioritisation also opens up the opportunity for populistic politicians to even go so far to say that the EU highlights the rule of law and cares much less about democracy, precisely because it has serious challenges with its own democratic legitimacy, as the bulk of literature on its democratic deficit suggests. ${ }^{25}$

\section{Misperceptions Three: Violations}

From very early on, the European Parliament was especially keen to point out that the Orbán government violates basic values of the EU. As the new Hungarian media legislation was to be passed in 2011, many members of the European Parliament protested against it by taping their mouths with band-aids and holding up signs reading "censored", suggesting that the modifications were evidence of an "authoritarian decay" (Schult 2011). Two years later, Rui Tavares, a Portuguese MEP, put forward a detailed report on Hungarian constitutional developments, which was approved by the European Parliament on 3 July 2013 (the Hungarian government claimed that the report was merely a conspiracy

${ }^{24}$ UK House of Lords, A and others v Secretary of State for the Home Department [2004] UKHL 56, para 237 by Baroness Hale of Richmond: "Democracy values each person equally. In most respects, this means that the will of the majority must prevail. But valuing each person equally also means that the will of the majority cannot prevail if it is inconsistent with the equal rights of minorities". Finding an appropriate balance is not easy, as the Swiss referendum of 2009 on a minaret ban very persuasively shows. Also very (in)famous is the headline of the Daily Mail of 4 November 2016, describing the judges of the High Court as enemies of the people because they denied making use of the royal prerogative to trigger Brexit.

${ }^{25}$ Müller (2015) offers serious arguments against these allegations. 
of the left). In 2017, Judith Sargentini submitted a detailed report about Hungary and a proposal to call on the Council to determine the existence of a clear risk of a serious breach by Hungary of the values on which the Union is founded (Sargentini 2017). In January 2020, European Parliament voted for more vigorous actions against Hungary and Poland.

This eagerness is in sharp contrast to the reluctance of the Commission to initiate those proceedings (at least against Hungary; in the case of Poland, the Commission is much more proactive). ${ }^{26}$ Article 7 TEU requires a serious breach of the values of the Union, which must go far beyond a simple violation of the treaties, such as a not implementing a directive, which raises a number of questions.

A serious breach of the EU's foundational values is not necessarily equivalent to a series of breaches of EU law. Nonetheless, a certain number of judgements of the Court of Justice of the European Union (CJEU) or the European Court of Human Rights (ECtHR) finding a EU member state continuously violating values of the EU may indicate that the given member state has seriously breached those values, and hence they may trigger a procedure according to Article 7 TEU (Gormley 2017, p. 75). This is a very tempting idea, explaining a serious breach precisely in this way, as it relies on court judgements which by definition are stemming from a neutral institution. That is why this argument deserves a closer look.

One serious objection-and this will rouse every "rogue government"-is that an infringement procedure according to Article 258 TFEU sufficiently deals ${ }^{27}$ with an alleged violation of EU law, and that a further procedure according to Article 7 TEU is not only unnecessary but also illegal. ${ }^{28}$ The government in question is obliged to "take the necessary measures to comply with the judgment of the Court" (art. 260(1) TFEU). If the government complied with the judgement of the CJEU, it will (like Hungary did) object to the consideration of these infringement

\footnotetext{
${ }^{26}$ The reluctance might also be explained by rational calculation based upon expected behaviour, Closa (2018). Moreover, the general perception is that the Commission seems to have learned the lesson from the Hungarian case and is much tougher in the case of Poland, see e.g. with further references Adamski (2019, p. 652).

${ }^{27}$ Kochenov and Pech (2015) allege the leniency of the Commission.

${ }^{28}$ For serious counter-arguments for a parallel applicability, see Schmidt and Bogdanowicz (2018).
} 
procedures as evidence of a serious breach of the fundamental values of the EU.

Firstly, a typical argument is that the Commission was satisfied with the compliance, and hence there is no reason to bury the hatchet. Secondly, it can be argued that taking these infringement procedures into account would violate the "ne bis in idem" principle, in not being prosecuted or punished twice for the same offence. Ne bis in idem is rather an individual right and therefore less applicable to states. But this distinction might not be as relevant as the relationship between Article 258 TFEU and Article 7 TEU. Even if both of these procedures aim to point out that a member state does not comply with the requirements of the European acquis, their relation to each other is much less like a second punishment for the same crime (as it is the core of the ne bis in idem principle), but rather punishing a reoffending recidivist. Thirdly, it can be asked how many successful infringement procedures within which period of time indicate a serious breach. ${ }^{29}$ Going beyond the question of quantity, there is a harder nut to crack: the question of quality of EU law violations. In the case of Hungary, the forced retirement of judges was qualified by the Commission as a mere violation of the anti-discrimination directive ${ }^{30}$ (the judicial independence was not even mentioned). Not only that, the Commission saw the reorganisation of the data protection ombudsman as an infringement of the independence of the data protection authorities according to the data protection directive, the vexation of the NGOs as a violation of the freedom of capital, ${ }^{31}$ and the dismissal of the President of the former Supreme Court of Hungary as no reason for an infringement procedure. Thus, the former President had to seek remedy before the European Court of Human Rights himself. ${ }^{32}$ Nevertheless, Hungary is not the only member state with compliance problems. Germany, for instance, infringed the same anti-discrimination directive in the case of

\footnotetext{
${ }^{29}$ Taking the example of Hungary, it might be argued that the forced early retirement of judges (CJEU, Case C-286/12, Commission v Hungary, ECLI:EU:C:2012:687) or the violation of institutional independence of Hungary's data protection ombudsman (CJEU Case C-288/12, Commission v Hungary. ECLI:EU:C:2014:237) would not necessarily be enough.

${ }^{30}$ Directive 2000/78/EC establishing a general framework for equal treatment in employment and occupation (OJ 2000 L 303, p. 16).

${ }^{31}$ Case C-78/18, Commission/Hungary, not yet decided.

${ }^{32}$ ECtHR, 23 June 2016, Baka v Hungary, no. 20261/12.
} 
prosecutors as Hungary did, ${ }^{33}$ and was also found to be violating the independence of the data protection authorities. However, this alone does not qualify for an Article 7 TEU procedure.

Illiberal politicians very gladly apply these two arguments in case of any accusations: relativism and a very formal understanding of the rule of law. First, they highlight that the governments prosecuting and condemning them are not better at all, as they themselves are liable for similar infringements, so they simply pick and choose the newer or smaller member states to demonstrate some undeserved moral high ground, ${ }^{34}$ but otherwise pursue transactional Realpolitik (let us call this argument Quod licet Iovi non licet bovi). Secondly, rogue governments claim that accusations are unfounded because their opponents are not able to define why the socalled rule of law was infringed, and therefore, no opportunity is given to discuss the accusation.

\section{IlL-Suited Responses}

As it was pointed out, the European Parliament was very eager to condemn the illiberal tendencies of the Hungarian government, and to activate Article 7 TEU. The Commission, on the contrary, was much more restrained. It did not push Article 7 TEU too much, and one is under the impression that the infringement procedures initiated by the Commission were rather half-hearted responses. ${ }^{35}$ On the one hand, European institutions are engaged in shadow-boxing around the basic values of the EU and have adopted a Rule of law framework to prevent emerging threats to the rule of law (but have nonetheless abstained from a similar tool kit for the several other values enshrined in Art 2 TEU). ${ }^{36}$ On the other hand, they have been rather shy engaging in a direct conflict

${ }^{33}$ CJEU Case C-159/10 and C-160/10, Gerhard Fuchs and Peter Köhler v Land Hessen (ECLI:EU:C:2011:508).

${ }^{34}$ Very similar was the situation in the case of Austria, which was severely condemned for the participation of Mr. Haider and his Freedom Party (FPÖ) in the federal government. But Italy, governed at the same time by the very controversial Mr. Berlusconi, was not condemned, see, e.g., Hummer (2013, p. 136).

${ }^{35}$ Schmidt and Bogdanowicz (2018) also argue that the Commission has not made best use of the available remedies.

${ }^{36}$ Or one might thus express ambivalence that there is a preference for the rule of law, Schorkopf (2016, p. 158). 
in those areas where the Commission has real investigative powers and resources, ${ }^{37}$ and could have achieved real success (at the cost of a real conflict, of course)..$^{38}$

In fact, the European Commission missed the opportunities to shorten the Hungarian regime's money supply, which could have been much more efficient than some Rule of law frameworks and assessments which are good for condemning a regime morally. But these kinds of exercises do not help all that much if a regime itself is morally very flexible. It is built on crony capitalism (Rubin 2015), business thriving due to a nexus between the business and the political elite. The political elite narrows the field of real market economy and tilts the conditions in order to build monopolies or oligopolies, and the rent-seeking ${ }^{39}$ business elite profiteering from these conditions becomes a generous partner of the political class and supports the political struggle. One speaks of a "symbiotic relationship between big government, big business, and big labor aligned in a cooperative enterprise in which the government picks economic winners and losers and subsidizes and protects particular favored industries, firms, and interest groups, has come to be known as crony capitalism" (Zywicki 2015 , p. 78). This description would more or less fit Hungary, and many say that Hungary has shifted to a model where "business success is intertwined with political power" and is "becoming a miniature version of Vladimir Putin's Russia” (Buckley and Byrne 2017).

Crony capitalism and rent-seeking business oligarchs can only work if there are some political barriers for entering the market ${ }^{40}$ precisely

${ }^{37}$ The Commission is much more eager in the case of Poland than in the case of Hungary, since the bullying of the CEU and the NGOs the Commission seems to have become more rigorous (Case C-66/18, Commission/Hungary and case C-78/18, Commission/Hungary, respectively, none of them decided yet). Nonetheless it would be an overstatement to say that it made use of all available tools. Closa provides a rational explanation for the strategy of the Commission, see Closa (2018).

${ }^{38}$ As the Commission achieved some success in the case of the forced retirement of the Hungarian judges by requesting accelerated procedures.

${ }^{39}$ The concept of rent-seeking is basically an invention of Tullock, see Rowley and Houser (2012).

${ }^{40}$ During the last decade, there was a massive CJEU case law regarding newly enacted state monopolies in Hungary which restrict market access, cf. e.g. case C-179/14, Commission/Hungary, regarding state monopoly on leisure and meal vouchers, case C-171/17, Commission/Hungary, regarding national mobile payment system; or the national tobacco concession, ECtHR Judgement of 13 January 2015, Vékony v. Hungary (Application no. 65681/13). Instructively Varju and Papp (2016). 
because the rent-seeking makes the goods and services more expensive. Hence, under normal circumstances, the rent-seekers are less innovative and therefore less successful. Barriers to entering the market are in logical contradiction to the concept of the internal market without frontiers in which the free movement of goods, persons, services and capital is ensured, as it is required by the TFEU. Moreover, the internal market is the area where the Commission is the most powerful and could takethough politically less spectacular-more effective measures than have never-ending debates about the values of the Union.

Nevertheless, a series of dubious measures was not sanctioned by the EU. If the rapid enrichment of the son-in-law or the neighbour of $\mathrm{Mr}$. Orbán is really the result of corrupt tendering practices, bid-rigging and anti-competitive behaviour, as many suggest, the Commission has all the power to investigate, even to launch infringement procedures. Even if the OLAF cannot launch a criminal investigation, it can produce a dossier for the Commission in order to facilitate an investigation, which again can make use of different tools should EU rules ever be violated, especially if EU funds were misused.

The same is true for the Hungarian sport subsidising tax scheme, through which, as many suggest, the business and political elite is very well connected. This scheme enables business to support even professional team sport instead of paying the same sums as taxes and explains how a football stadium appeared in the village of Viktor Orbán. Although the Commission investigated this tax scheme, because professional sport teams are under normal circumstances business undertakings, and to them the rules of the internal market are applicable (Parrish 2003), it was found to be compatible with state aid rules of the EU (European Commission $2011)$.

Very suspicious was also the Hungarian Golden Visa scheme (Martini 2018), which not only enabled one to get permanent residence in this Schengen country, but also profited handsomely for some close friends of the regime. The new Hungarian nuclear power plant to be built in the town of Paks could have raised not only environmental but also competition and security policy issues as well. Instead of being very scrupulous regarding Hungary's intention to involve Russian nuclear technology, the Commission, according to some sources, lent a hand to the Hungarian government on how to find a loophole in the EU public procurement regime (Valero 2017) and also approved Hungary's financial support for the construction of them (European Commission 2017). 
A further issue was the creation of a gargantuan media holding in the summer of 2018, as many rich businessmen close to Orbán created a foundation (Közép-Európai Sajtó és Média Alapitvány-Central European Press and Media Foundation), and very generously donated their media undertakings for this entity. In doing so, they produced the largest media company in Hungary owning a number of print newspapers and magazines, TV and radio stations and news websites, which not only questions media plurality but that of competition law as well. Although national legislation created a loophole for this construction, being freed from the scrutiny of the competent national authorities, this should not stop the Commission from taking a closer look.

The recent initiative by the European Commission to protect the Union's budget in case of generalised deficiencies as regards the rule of law in the member states (European Commission 2018) rather satisfies the demands of old member states. Seeing as it might have a disciplinary effect, it can be seen as a step in the right direction. But there are still some caveats. The generalised deficiencies are at the very least unclear, which hampers its effectiveness. Moreover, it sharpens the conflict between new and old member states, because the new ones do not necessarily see the financial support as a generosity but as a bargained price for opening their infant markets for the developed Western countries by the accession, with EU funding simply offsetting the losses. Cutting these sources would mean an impetus, at least for the new member states, to introduce measures to protect their own markets, and, of course, to capitalise on them politically (describing them as punishment for defending the national interest) (Adamski 2019, pp. 645-649).

\section{Conclusion}

Since 2010, there has been an ongoing discussion in Europe as to whether Hungary is violating the fundamental values of the European Union, and if so, what to do with it. For some, Hungary is a deterrent example; for others, it is a guidebook on how to exploit the benefits of the membership and getting away with it.

The Hungarian government has a very transactional position in relation to the EU and is rather immune to discussions on its core principles. ${ }^{41}$

${ }^{41}$ Well-documented by Kelemen (2017). 
It often describes them as pointless moral debates on diverging political philosophies. ${ }^{42}$ There are several circumstances supporting this value relativism. There is, on the one hand, no value unity in the EU, and no authority to define the so-called common values. The conceptual core of these values might be common, but there are so many niceties and particulars that it is very hard to establish a canon of these values. This inherent inhomogeneity of the European Union (united in diversity, as the motto goes) can be very easily exploited in a postmodern world of philosophical deconstruction by highlighting natural contradictions and variations, which might result also in the destruction of these values. This is being attempted by the Hungarian government.

Therefore, the EU should make an effort to neutralise the dispute ${ }^{43}$ and to make the best use of those competences, powers and procedures which are rather immune to the sophistry of the Hungarian government, such as the internal market, competition rules. The Commission, while making some progress, has not effectively used its powers.

The conclusion comes very close to Kennan's long telegram: "We must have courage and self-confidence to cling to our own methods and conceptions of human society. (...) The greatest danger that can befall us in coping with this problem of Soviet communism, is that we shall allow ourselves to become like those with whom we are coping". One way out is the even-handed application of EU law for all member states, new and old, big or small.

\section{REFERENCES}

Adamski, Dariusz. 2019. The Social Contract of Democratic Backsliding in the "New EU" Countries. Common Market Law Review 56: 623-666.

Amtenbrink, F., and J. de Haan. 2006. Reforming the Stability and Growth Pact. European Law Review 31: 402-413.

Avbelj, Matej. 2015. Pluralism and Systemic Defiance in the European Union. In The Enforcement of EU Law and Values: Ensuring Member States' Compliance, ed. A. Jakab and D. Kochenov, 44-64. Oxford: Oxford University Press.

Bachmann, Theresa. 2019. Der Nachbarschaftsraum nach Artikel 8 EUV. BadenBaden: Nomos.

${ }^{42}$ In worse cases, even calling it a political witch-hunt, see, e.g., Bakó (2019).

${ }^{43}$ For a plea for a broad EU debate on its core principles, see Chapter 14. 
Badó, Attila. 2014. 'Fair' Selection of Judges in a Modern Democracy. In Fair Trial and Judicial Independence, ed. Attila Badó, 27-58. Heidelberg: Springer.

Bakó, Bea. 2018. Sargentini vajon sorosnak, vagy a fidesznek dolgozik? azonnali.hu. https://azonnali.hu/cikk/20180909_sargentini-vajon-sorosnakvagy-a-fidesznek-dolgozik. Accessed 21 February 2020.

Bakó, Bea. 2019. Mi történt brüsszelben magyarország hetes cikkes meghallgatásán? azonnali.hu. https://azonnali.hu/cikk/20190916_mi-tortent-bru sszelben-magyarorszag-hetes-cikkes-meghallgatasan. Accessed 21 February 2020.

BBC. 2006. We Lied to Win, Says Hungary PM. http://news.bbc.co.uk/2/hi/ europe/5354972.stm. Accessed 21 February 2020.

Bíró, Marianna. Az Orbán-rendszer nagy kérdése, hogy tényleg elbukik-e a Nyugat. index.hu. https://index.hu/belfold/2019/02/20/tolgyessy_peter_ eotvos_csoport_eloadas_rendszervaltas_orban/. Accessed 21 February 2020.

Boffey, Daniel. 2019. Hungary's Far-Right Government Vilifies Finland over Rule of Law Inquiry. The Guardian. https://www.theguardian.com/ world/2019/aug/13/hungary-far-right-government-finland-rule-law-inq uiry. Accessed 21 February 2020.

Brems, Eva. 1996. The Margin of Appreciation Doctrine in the Case-Law of the European Court of Human Rights. Zeitschrift für ausländisches öffentliches Recht und Völkerrecht 56: 230-314.

Brouillette, Amy, and J. van Beek. 2012. Hungarian Media Laws in Europe. Budapest: Central European University.

Buckley, N., and A. Byrne. 2017. Viktor Orban's Oligarchs: A New Elite Emerges in Hungary. Financial Times. https://www.ft.com/content/ecf 6fb4e-d900-11e7-a039-c64blc09b482. Accessed 21 February 2020.

Chronowski, N., and A. Vincze. 2019. Az Alkotmánybíróság határozata a Magyar Nemzeti Bank kiadmányozási joga ügyében: A közjogi személyek alkotmányjogi panasza. Jogesetek Magyarázata: 3-12.

Chronowski, N., and M. Varju. 2016. Two Eras of Hungarian Constitutionalism: From the Rule of Law to Rule by Law. Hague Journal on the Rule of Law 8: 271-289.

Closa, Carlos. 2018. The Politics of Guarding the Treaties: Commission Scrutiny of Rule of Law Compliance. Journal of European Public Policy. https://doi. org/10.1080/13501763.2018.1477822.

Di Gregorio, Angela. 2019. Constitutional Courts and the Rule of Law in the New EU Member States. Review of Central and East European Law 44: 202-231.

Doukas, Dimitrios. 2005. The Frailty of the Stability and Growth Pact and the European Court of Justice: Much Ado About Nothing? Legal Issues of Economic Integration 32: 293-312. 
Ésik, Sándor. 2018. A Sargentini-jelentés egy fércmunka. azonnali.hu. https:// azonnali.hu/cikk/20180910_a-sargentini-jelentes-egy-fercmunka. Accessed 21 February 2020.

European Commission. 2011. Supporting the Hungarian Sport Sector via Tax Benefit Scheme. https://ec.europa.eu/competition/state_aid/cases/240466/ 240466_1271180_52_3.pdf. Accessed 21 February 2020.

European Commission. 2017. State Aid: Commission Clears Investment in Construction of Paks II Nuclear Power Plant in Hungary. https://europa. eu/rapid/press-release_IP-17-464_en.htm. Accessed 21 February 2020.

European Commission. 2018. COM (2018) 324 Final: Proposal on the Protection of the Union's Budget in Case of Generalised Deficiencies as Regards the Rule of Law in the Member States.

Fekete, Balázs. 2016. Alternatív kommentár az EUSZ 7. Cikkéhez. Közjogi Szemle 9 (2): 1-11.

Fleck, Zoltán. 2014. A Comparative Analysis of Judicial Power, Organisational Issues in Judicature and the Administration of Courts. In Fair Trial and Judicial Independence, ed. Attila Badó, 3-26. Heidelberg: Springer.

Franchini, Claudio. 2004. European Principles Governing National Administrative Proceedings. Law and Contemporary Problems 68: 183-196.

Gergely, Márton. 2017. Tölgyessy Péter: Orbán diadalmasan menetel a zsákutcába. hvg.hu. https://hvg.hu/itthon/20170511_Tolgyessy_Peter_Orban_diadal masan_menetel_a_zsakutcaba. Accessed 21 February 2020.

Gormley, Laurence W. 2017. Infringement Proceedings. In The Enforcement of EU Law and Values: Ensuring Member States' Compliance, ed. A. Jakab and D. Kochenov, 65-78. Oxford: Oxford University Press.

Gorondi, Pablo. 2018. Ukraine's Hungarian Minority Threatened by New Education Law. AP News. https://www.apnews.com/2215f81c9f86412c888f50a5 81ff9826. Accessed 21 February 2020.

Griffith, John A.G. 1977. Politics of Judiciary. London: Fontana Press.

Häde, Ulrich. 2005. Unabhängigkeit für die ungarische Nationalbank? Zum Status der Zentralbanken von Mitgliedstaaten mit Ausnahmeregelung. Europäische Zeitschrift für Wirtschaftsrecht 16: 679-682.

Halmai, Gábor. 2014. An Illiberal Constitutional System in the Middle of Europe. European Yearbook of Human Rights 14: 497-514.

Halmai, Gábor. 2018a. Abuse of Constitutional Identity: The Hungarian Constitutional Court on Interpretation of Article (E) (2) of the Fundamental Law. Review of Central and East European Law 43: 23-42.

Halmai, Gábor. 2018b. The Application of European Constitutional Values in EU Member States, The Case of the Fundamental Law of Hungary. European Journal of Law Reform 20: 10-34. 
Hanley, E., and D.J. Treiman. 2004. Did the Transformation to PostCommunism in Eastern Europe Restore Pre-Communist Property Relations. European Sociological Review 20: 237-252.

Hummer, Waldemar. 2013. Eine Verfassung für die Europäische Union - eine Sicht aus Österreich. In Eine Verfassung für die Europäische Union: Beiträge zu einer grundsätzlichen und aktuellen Diskussion, ed. Heiner Timmermann, 107-145. Wiesbaden: Springer VS.

Hwang, Shu-Perng. 2013. Grundrechtsschutz unter der Voraussetzung des europäischen Grundkonsenses? Kritische Bemerkungen zur „margin of appreciation"-Doktrin am Beispiel des Inzest-Urteils des EGMR vom 12.4.2012. EuR Europarecht 48: 307-322.

Ilonszki, G., and S. Kurtán. 2007. Hungary. European Journal of Political Research 46: 966-973.

Itzcovich, Giulio. 2015. On the Legal Enforcement of Values, the Importance of the Institutional Context. In The Enforcement of EU Law and Values: Ensuring Member States' Compliance, ed. A. Jakab and D. Kochenov, 28-43. Oxford: Oxford University Press.

Jacobsohn, Gary J. 2006. Constitutional Identity. The Review of Politics 68: 361397.

Jakab, András. 2009. Two Opposing Paradigms of Continental European Constitutional Thinking: Austria and Germany. International \& Comparative Law Quarterly 58: 933-955.

Jowell, Jeffrey. 2007. Rule of Law and Its Underlying Values. In The Changing Constitution, ed. J. Jowell and O. Dawn, 5-24. Oxford: Oxford University Press.

Kelemen, Katalin. 2017. The New Hungarian Constitution: Legal Critiques from Europe. Review of Central and East European Law 42: 1-49.

Kelemen, D., and L. Pech. 2018. Why Autocrats Love Constitutional Identity and Constitutional Pluralism: Lessons from Hungary and Poland. RECONNECT-Working Paper No. 2. https://reconnect-europe.eu/wp-content/ uploads /2018/10/RECONNECT-WorkingPaper2-Kelemen-Pech-LP-KO. pdf. Accessed 21 February 2020.

Kellerhals, A., and T. Baumgartner. 2014. EU Neighbourhood Policy-Survey and Perspectives. Zürich: Schulthess.

Kischel, Uwe. 2019. Comparative Law. Oxford: Oxford University Press.

Kochenov, Dimitry. 2017. Busting The Myths Nuclear: A Commentary on Article 7 TEU. EUI Working Paper LAW 2017/10.

Kochenov, D., and L. Pech. 2015. Monitoring and Enforcement of the Rule of Law in the EU: Rhetoric and Reality. European Constitutional Law Review 11: $512-540$. 
Kombos, Constantinos. 2010. The Esoteric Dimension of Constitutional Pluralism. In The European Union Legal Order After Lisbon, ed. P. Birkinshaw and M. Varney, 291-323. Alphen aan den Rijn: Kluwer.

Kosař, D., and K. Šipulová. 2018. The Strasbourg Court Meets Abusive Constitutionalism: Baka v. Hungary and the Rule of Law. Hague Journal on the Rule of Law 10 (1): 83-110.

Kovács, Ágnes. 2019. Tájkép sötét kerettel: az alkotmánybíróság „MNBhatározata" - szkeptikus olvasat. Fundamentum 1-2: 109-120.

Kovács, Balázs Á. 2012. Hungary, Nations in Transit. Freedom House. https:// freedomhouse.org/sites/default/files/NIT2012Hungary_final.pdf. Accessed 21 February 2020.

Krekó, P., and E. Zsolt. 2018. Orbán's Laboratory of Illiberalism. Journal of Democracy 29: 39-51.

Lachmayer, Konrad. 2017. Questioning the Basic Values and Jörg HaiderAustria. In The Enforcement of EU Law and Values, ed. A. Jakab and D. Kochenov, 436-455. Oxford: Oxford University Press.

Lenaerts, Koen. 2020. New Horizons for the Rule of Law Within the EU. German Law Journal 21: 29-34.

Mader, Oliver. 2019. Enforcement of EU Values as a Political Endeavour: Constitutional Pluralism and Value Homogeneity in Times of Persistent Challenges to the Rule of Law. Hague Journal on the Rule of Law 11: 133-170.

Magyar, Bálint (ed.). 2013. A Magyar polip - A posztkommunista maffiaállam. Budapest: Noran Libro.

Martini, Maíra. 2018. Hungary's Controversial Golden Visa Scheme: Ins and Outs. https://voices.transparency.org/hungarys-controversial-golden-visa-sch eme-ins-and-outs-daf8961df85d. Accessed 21 February 2020.

Mayer, Franz. 2015. Defiance by a Constitutional Court-Germany. In The Enforcement of EU Law and Values: Ensuring Member States' Compliance, ed. A. Jakab and D. Kochenov, 403-421. Oxford: Oxford University Press.

McLaughlin, Daniel. 2018. Ukraine Reassures Its Ethnic Hungarians Amid Bitter Row with Budapest. https://www.irishtimes.com/news/world/eur ope/ukraine-reassures-its-ethnic-hungarians-amid-bitter-row-with-budapest1.3663338. Accessed 21 February 2020.

Morison, John. 2007. Models of Democracy: From Representation to Participation? In The Changing Constitution, ed. J. Jowell and O. Dawn, 134-159. Oxford: Oxford University Press.

Müller, Jan W. 2015. Should the EU Protect Democracy and the Rule of Law inside Member States? European Law Journal 21: 141-160.

Parrish, Richard. 2003. Sports Law and Policy in the European Union. Manchester: Manchester University Press.

Poptcheva, Eva-Maria. 2015. Member States and the Rule of Law: Dealing with a Breach of EU Values. European Parliamentary Research Service 
(Briefing March). http://www.europarl.europa.eu/RegData/etudes/BRIE/ 2015/554167/EPRS_BRI(2015)554167_EN.pdf. Accessed 21 February 2020.

Pöschl, Magdalena. 2014. Gleichheitsrechte. Buchreihe Handbuch der Grundrechte in Deutschland und Europa, Bd. VIl/1, ed. D. Merten and H.-J. Papier. Heidelberg: C.F. Müller.

Rosenfeld, Michel. 2012. Constitutional Identity. In The Oxford Handbook of Comparative Constitutional Law, ed. M. Rosenfeld and A. Sajó, 756-776. Oxford: Oxford University Press.

Rowley, C., and D. Houser (eds.). 2012. The Intellectual Legacy of Gordon Tullock. Public Choice Sonderbeft 152 (1): 29-46.

Rubin, Paul H. 2015. Crony Capitalism. Supreme Court Economic Review 23: $105-120$.

Sargentini, Judith. 2017. Report on a Proposal Calling on the Council to Determine, Pursuant to Article 7(1) of the Treaty on European Union, the Existence of a Clear Risk of a Serious Breach by Hungary of the Values on Which the Union Is Founded (2017/2131(INL)).

Saunders, Ben. 2010. Democracy, Political Equality, and Majority Rule. Ethics 121: 148-177.

Scheppele, Kim L. 2013. The Rule of Law and the Frankenstate: Why Governance Checklists Do Not Work. Administration, and Institutions 26: $559-562$.

Schimmelfennig, F., and F. Trauner (eds.). 2009. Post-accession compliance in the EU's new member states. European Integration online Papers Sonderheft 2.

Schmahl, Stefanie. 2000. Die Reaktionen auf den Einzug der Freiheitlichen Partei Österreichs in das österreichische Regierungskabinett - Eine europaund völkerrechtliche Analyse. Europarecht: 819-836.

Schmidt, M., and P. Bogdanowicz. 2018. The Infringement Procedure in the Rule of Law Crisis: How to make Effective Use of Article 258 TFEU. Common Market Law Review 55: 1061-1100.

Schorkopf, Frank. 2016. Wertesicherung in der Europäischen Union. Prävention, Quarantäne und Aufsicht als Bausteine eines Rechts der Verfassungskrise. Europarecht 51 (2): 147-164.

Schult, Christoph. 2011. Media Law Controversy Hungary's Orbán Gets Frosty Reception in European Parliament. Der Spiegel. https://www.spiegel.de/int ernational/europe/media-law-controversy-hungary-s-orban-gets-frosty-recept ion-in-european-parliament-a-740400.html. Accessed 23 February 2020.

Tamanaha, Brian Z. 2004. On the Rule of Law: History, Politics, Theory. Cambridge: Cambridge University Press.

Tamanaha, Brian Z. 2006. Law as Means to an End. Cambridge: Cambridge University Press. 
The Economist. 2019. The Entanglement of Powers How Viktor Orban Hollowed Out Hungary's Democracy. https://www.economist.com/bri efing/2019/08/29/how-viktor-orban-hollowed-out-hungarys-democracy. Accessed 21 February 2020.

The Guardian. 2006. Hungary PM: we lied to win election. https://www.the guardian.com/world/2006/sep/18/1. Accessed 21 February 2020.

Tomkins, Adam. 2005. Our Republican Constitution. Oxford: Hart.

Valero, Jorge. 2017. Commission Told Hungary How to Win Approval for Russia-backed nuclear plant. Euractiv.com. https://www.euractiv.com/sec tion/energy/news/commission-told-hungary-how-to-win-approval-for-rus sia-backed-nuclear-plant/. Accessed 21 February 2020.

van der Schyff, Gerhard. 2016. EU Member State Constitutional Identity: A Comparison of Germany and the Netherlands as Polar Opposites. Zeitschrift für ausländisches öffentliches Recht und Völkerrecht 76: 167-191.

Varju, M., and M. Papp. 2016. The Crisis, National Economic Particularism and EU Law: What Can We Learn from the Hungarian Case? Common Market Law Review 53: 1647-1674.

Vincze, Attila. 2012. The New Hungarian Constitution: Redrafting, Rebranding or Revolution. Vienna Journal on International Constitutional Law 6: 88109.

Vincze, Attila. 2014. Wrestling with Constitutionalism: The Supermajority and the Hungarian Constitutional Court. Vienna Journal on International Constitutional Law 8: 86-97.

Vincze, Attila. 2015. Dismissal of the President of the Hungarian Supreme Court: ECtHR Judgment 'Baka v. Hungary'. European Public Law 21: $445-456$.

Vincze, Attila. 2018a. Hungary: Regulatory Bodies in an Illiberal Democracy. In Governance and Constitutionalism: Law, Politics and Institutional Neutrality, ed. B. Iancu and E. Tănăsescu, 119-133. London: Routledge.

Vincze, Attila. 2018b. Ist die Rechtsübernahme gefährlich. Zeitschrift für öffentliches Recht: 193-218.

von Bogdandy, A., and M. Ioannidis. 2014. Das systemische Defizit Merkmale, Instrumente und Probleme am Beispiel der Rechtsstaatlichkeit und des neuen Rechtsstaatlichkeitsaufsichtsverfahrens. Zeitschrift Für Ausländisches öffentliches Recht Und Völkerrecht 74: 283-328.

Westad, Odd A. 2017. The Cold War. New York: Basic Books.

Zywicki, Todd. 2015. Rent-Seeking, Crony Capitalism, and the Crony Constitution. Supreme Court Economic Review 23: 77-103. 
Open Access This chapter is licensed under the terms of the Creative Commons Attribution 4.0 International License (http://creativecommons.org/licenses/ by $/ 4.0 /$ ), which permits use, sharing, adaptation, distribution and reproduction in any medium or format, as long as you give appropriate credit to the original author(s) and the source, provide a link to the Creative Commons license and indicate if changes were made.

The images or other third party material in this chapter are included in the chapter's Creative Commons license, unless indicated otherwise in a credit line to the material. If material is not included in the chapter's Creative Commons license and your intended use is not permitted by statutory regulation or exceeds the permitted use, you will need to obtain permission directly from the copyright holder.

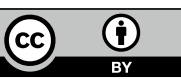

